\title{
LITHIUM ISOTOPES AS TRACERS OF GROUNDWATER CIRCULATION IN A PEATLAND
}

\author{
Philippe Négrel*, Romain Millot, Agnès Brenot, Clotilde Bertin
}

\author{
BRGM, 3 Avenue C. Guillemin, BP 36009, 45060 Orléans Cedex 02, FRANCE.
}

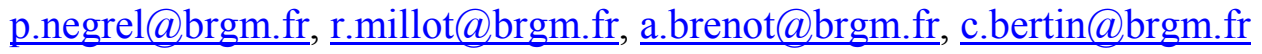

\section{Abstract}

Water circulation in the peat bog of a maar depression in the Massif Central (France) was traced with lithium isotopes on water samples collected in the area from springs, surface- and groundwaters, as well as on solid samples taken from peat bogs.

Lithium contents fluctuate significantly in the groundwaters, ranging from $0.01 \mu \mathrm{mol} . \mathrm{L}^{-1}$ in springs feeding the peat bog, up to $28 \mu \mathrm{mol} . \mathrm{L}^{-1}$ in the groundwater collected in the peat bog. Lithium-isotope compositions $\left(\delta^{7} \mathrm{Li}, \%\right.$ ) are extremely variable within the site, ranging from $+12 \%$ in the stream draining the area up to a ${ }^{7} \mathrm{Li}$-rich value of $+1226 \%$ in groundwater from the peat bog. The $\delta^{7} \mathrm{Li}$ values in the streams agree with those reported in the literature for surface waters, while those of groundwater are far beyond the range of values measured in nature.

In the present study, we explain the extremely enriched ${ }^{7} \mathrm{Li}$ signature of the groundwaters by an external input due to Ca-amendment, used in local agriculture. The relationships between Li content and $\mathrm{Ca}, \mathrm{Mg}$ and $\mathrm{HCO}_{3}$ as well as the lack of a relationship between $\mathrm{Li}$ and $\mathrm{Na}$ plead in favour of ${ }^{7} \mathrm{Li}$ enriched carbonate amendments. This hypothesis was tested by Li-isotope analyses on the peat and on several amendment samples (carbonates and NPK fertilizers), confirming the potential role of amendments in the control of $\mathrm{Li}$ isotopes in peatland groundwater and showing high $\delta^{7} \mathrm{Li}$ values in fertilizers. Application of $\delta^{7} \mathrm{Li}$ ratios to peatland waters provides a unique perspective on the hydrogeochemical dynamics at the scale of this site, as the $\delta^{7} \mathrm{Li}$ values for the surface water were quasi constant throughout the survey period, and the peatland groundwater does not supply the surface-water runoff and may evolve as a stagnant system. To conclude, the water within the peatland exhibits very high $\delta^{7} \mathrm{Li}$ values consistent with artificially enriched ${ }^{7} \mathrm{Li}$ associated with $\mathrm{Ca}$ amendments. This study open a new field for Li isotope investigations in hydro-systems and potential utility of Li isotopes as environmental tracers.

Keywords: peatland, groundwater, Li isotopes, Massif Central

\footnotetext{
* corresponding author
} 


\section{1 - Introduction}

A wetland is an area covered at least part-time by usually quite shallow water. Wetlands can be natural or artificial, permanent or temporary, and the water in them can be static or flowing, and fresh, brackish or salty. Wetlands form where water collects in a low-lying area with poor drainage. The water filling a wetland can have many origins: precipitation is a major source of water for many wetlands, but others are maintained by water that periodically overflows from rivers, lakes, etc., whereas a third source of water for wetlands is groundwater. All three sources generally deliver water to wetlands in regular cycles, based on the natural cycle of water through the hydrosphere. It is also worth noting that understanding the hydrology of a wetland is primordial for efficient flood control, paleoclimate analyses, and studying its role in the overall ecology.

The present study investigates the use of Li and its isotopes as a proxy of ground-to-surface water exchanges in a peatland from a mire-lake complex in the French Massif Central, as the capability of Li isotopes as hydrogeological tracers was earlier demonstrated by Hogan and Blum (2003). As one aim of the work was to determine geochemical constraints on the hydrological functioning of a peatland, our primary objective was to constrain hydro-reservoir signatures and the exchanges of water and solutes with adjacent ground and uplands. One particularly important aspect of this work was to evaluate the mechanisms of water and solute transfer between the reservoirs by applying Li as a new isotopic tracer.

Lithium has two stable isotopes of mass 6 and 7 , with natural abundances of $7.5 \%$ and $92.5 \%$ respectively. Lithium is a mobile element that tends preferentially to go into the fluid phase during water/rock interactions. The relative mass difference between the two isotopes is considerable at $17 \%$, generating significant mass-dependant fractionation during geochemical processes. The range of variation in lithium-isotope compositions is more than $50 \%$ in geological materials (see Coplen et al., 2002; Tomascak, 2004 for data compilation). As Li is 
60

a recently developed isotopic tracer, not all the processes that could induce and control isotopic fractionation are as yet well constrained. However, in the context of water/rock interactions, numerous studies (Huh et al., 1998, 2001; Pistiner et al., 2003; Kisakurek et al., 2004, 2005; Pogge von Strandmann et al., 2006; Millot et al., 2007, 2010a, 2010b) have clearly shown that isotopic fractionation supports the enrichment of the heavy isotope $\left({ }^{7} \mathrm{Li}\right)$ in solution, the light isotope $\left({ }^{6} \mathrm{Li}\right)$ being preferentially retained in secondary weathering minerals. Silicate rocks display $\mathrm{Li}$ isotope compositions ranging from -2 to $+10 \%$ (Coplen et al., 2002; Teng et al. 2004), that of seawater is $\sim+31 \%$ (Millot et al., 2004), river water has intermediate isotopic compositions ( +6 to $+23 \%$, Huh et al., 1998), and saline (thermomineral) water generally has isotopic compositions in the range of 0 to $+15 \%$ (Millot and Négrel, 2007, Millot et al., 2010b) although Falkner et al. (1997) found Li isotopic compositions in the range of +17 to $+35 \%$ in hot spring water from Lake Baikal.

Here, we present the first results of $\mathrm{Li}$ and its isotopes in all reservoirs of a peatland (groundwater, surface water, rainwater, wastewater, and solid peat samples) in order to evaluate the potential of $\mathrm{Li}$ isotopes as effective tracers of the connections between groundand surface waters in a wetland. We also explore the role of groundwater in supplying surface-water output from a peatland, using $\mathrm{Li}$ isotopes as a new probe for such characterization.

\section{2 - General setting}

The Narces de la Sauvetat peatland is located in the French Massif Central, which is the main volcanic province in France (Brousse and Lefevre, 1990) and the largest magmatic province of the West-European Rift system (Michon and Merle, 2001). Alkali basaltic volcanism is widespread in the Massif Central, occurring as numerous small centres clustered into several fields (Fig. 1). The Narces de la Sauvetat peatland occupies a maar depression with lapilli tuff deposited on the flanks (Boivin and Gourgaud, 1978), one of the biggest maars in the Velay in 
view of its 1.5-km diameter and 90-m depth (Fig. 1) (Cubizolle et al., 2007; Tourman, 2007). A 37-m drill-hole on the edge of the peatland revealed $2 \mathrm{~m}$ of black peat with increasing clay content at depth. Below this lie sandy clay with peat debris from 2 to $3 \mathrm{~m}$, sandy gravel with variable clay content, and basalt debris from scoria and lava from 3 to $6.4 \mathrm{~m}$, and finally alternating sandy silt, sandy gravel and some clay layers from 6.4 to $37 \mathrm{~m}$.

Recent coring as part of this work in the central part of the peatland (Fig. 1), revealed 3.5 to $4 \mathrm{~m}$ of black peat overlying 1.5 to $2 \mathrm{~m}$ of lighter peat and then a clayey layer that forms an impervious barrier for groundwater. This recent coring showed around $6 \mathrm{~m}$ of peat deposits in the site and revealed the heterogeneity of the peat in the maar. The limit between the saturated and unsaturated zones lies around $-1.5 \mathrm{~m}$ in piezometer well Q1 and $-0.5 \mathrm{~m}$ in piezometer Q2, and the aquifer is everywhere unconfined (Fig. 1), Q2 being up-slope compared to Q1. All deposits (sand, gravel, etc.) are linked to the maar origin and, contrary to other maars in the Deves (Tourman, 2007), there are no lacustrine deposits.

The Narces de la Sauvetat is drained by a small stream, the Fouragettes, that represents the outlet of the area (Fig. 1: R1, altitude $1056 \mathrm{~m}$ ). One other surface water exists in the peatland (R2) with a very low discharge and a non perennial functioning (particularly during summer time). Several diffusive springs occur around the maar (Fig. 1), but most of them emerge on the western side (e.g. S5, altitude of about $1080 \mathrm{~m}$ ), reflecting the basal level of a basaltic aquifer. Other springs are S1 and S6. S1 emerges at an altitude of $1120 \mathrm{~m}$, but lies farther outside the maar; S6 emerges at an altitude of $1056 \mathrm{~m}$ and is more diffuse and may not be related to the maar, but could also reflect another basalt aquifer. A wastewater collector (EU) for two houses is located in the peatland (Fig. 1).

\section{3 - Material and methods}

\subsection{Material}


111 The site survey was carried out during one year, with a complete sampling of all selected

112 points once a month (Fig. 1). The piezometer wells were pumped before sampling when 113 approximately twice the well volume was removed before water sampling, the key parameter 114 being the stability of electrical conductivity. Surface- and ground-water samples were 115 collected in polyethylene bottles and separated into aliquots. Two of these were filtered 116 through pre-cleaned $0.45 \mu \mathrm{m}$ acetate filters using a pre-cleaned Nalgene filter apparatus; the 117 filtrate of one of the aliquots was further separated into two additional aliquots (100 and $1181000 \mathrm{ml})$. The latter was acidified with Suprapur $\mathrm{HNO}_{3}(\mathrm{pH} \sim 2)$ and stored in pre-cleaned 119 polyethylene bottles for major-cation analysis and lithium-isotope and Li-content 120 determinations.

121 For the Li-isotope investigation, groundwater samples from Q1 and -Q2 were analysed for 122 eight months (June to November, January and April), spring waters from S1, S5 and S6 were analysed once (August), wastewater was analysed once (June) and surface water (R1) was 124 analysed for six months (June to November).

125 Solid samples of brown and black peat were collected near the two piezometers Q1 and Q2 126 (Table 1). Near Q1, three samples were collected at 0-0.6 m, $1 \mathrm{~m}$ and $2 \mathrm{~m}$ depth, and a further 127 three samples were collected near Q2 (at surface, $0.3 \mathrm{~m}$ and $1 \mathrm{~m}$ depth). The samples were 128 oven-dried at $70{ }^{\circ} \mathrm{C}$ and powdered prior to analysis. In order to obtain representative aliquots 129 for the analyses, the samples were homogenized, quartered and dry-sieved through a $65 \mu \mathrm{m}$ 130 nylon mesh.

131 In addition, several samples of fertilizers (carbonaceous additives and NPK), carbonate matrix 132 (Mäerl) and agricultural additives (borax, $\mathrm{Li}-\mathrm{Cl}, \mathrm{Li}-\mathrm{OH}$ ) were collected and analysed for $\mathrm{Li}$ 133 contents and $\mathrm{Li}$ isotopes (Table 2). Carbonaceous additives consist either of fine white 134 powder or small grains (3-5 mm in size), while NPK consists only of small grains. The white 
135 powder was directly dissolved in an $\mathrm{HCl}-\mathrm{HNO}_{3}$ mixture, but the small grains were first

136 crushed and then dissolved in $\mathrm{HCL}-\mathrm{HNO}_{3}$ at ambient temperature in the laboratory.

137

138

139

140

141

142

143

144

145

146

147

148

149

150

151

152

153

\subsection{Methods}

The water samples were analysed by ion chromatography for major ions (accuracy 5-10\%), by inductively coupled plasma mass spectrometry for Li (accuracy 5\%), and by Gran's method ( $\mathrm{HCl}$ titration) for alkalinity (Négrel and Petelet-Giraud, 2005).

Lithium-isotope compositions were measured with a Neptune Multi-Collector ICP-MS (Thermo Fisher Scientific) used in the BRGM Isotope Geochemistry Laboratory (see Millot et al., 2004 for more details) and are reported in delta units as follows:

$$
\delta^{7} \mathrm{Li}(\% \mathrm{o})=\left(\frac{\left({ }^{7} \mathrm{Li} /{ }^{6} \mathrm{Li}\right)_{\text {sample }}}{\left({ }^{7} \mathrm{Li} /{ }^{6} \mathrm{Li}\right)_{\mathrm{L}-S V E C}}-1\right) \times 10^{3}
$$

The ${ }^{7} \mathrm{Li} /{ }^{6} \mathrm{Li}$ ratios were normalized to the L-SVEC standard solution (NIST SRM 8545) following the standard-sample bracketing method. Typical in-run precision on the determination of $\delta^{7} \mathrm{Li}$ is about $0.1-0.3 \%$ ( $\left(2 \sigma_{\mathrm{m}}\right.$, Millot et al., 2004; 2010a), but can be higher (up to $1 \%$ for one analysis due to the low signal for this sample, Table 3). Chemical separation of lithium from the matrix was achieved before mass analysis using $3 \mathrm{~mL}$ of cationic resin (BioRad $\mathrm{AG}^{\circledR}$ 50W-X12, 200-400 mesh) and $\mathrm{HCl}$ acid media $(0.2 \mathrm{~N})$ for $30 \mathrm{ng}$ of lithium. Blanks for the total chemical extraction were less than 20-30 pg of $\mathrm{Li}$, which is negligible since it represents a $10^{-3}$ blank/sample ratio. The accuracy and reproducibility of the total method (purification procedure + mass analysis) were tested by repeated measurement of a seawater sample (IRMM BCR-403) after separation of lithium from the matrix, for which we obtained a mean value of $\delta^{7} \mathrm{Li}=+30.8 \% \pm 0.4(2 \sigma, \mathrm{n}=15)$ over the duration of the analyses. This mean value is in good agreement with our long-term measurement $\left(\delta^{7} \mathrm{Li}=+31.0 \% \pm \pm 0.5,2 \sigma, \mathrm{n}=30\right.$, Millot et al. 2004). 
159 The $\delta^{7} \mathrm{Li}$ ratios and Li contents were measured on the solid peat samples and on the different

160 fertilizers and additives, using standard acid-dissolution procedures and chemical separation

161 of lithium from the matrix. For solid peat samples, a total digestion of the sample is necessary

162 before separation of Li from the matrix. About $50 \mathrm{mg}$ of crushed sample was dissolved in a

163 closed beaker with an ultrapure mixture of three acids - $4 \mathrm{ml} \mathrm{HF} \mathrm{(23N),} 1 \mathrm{ml} \mathrm{HNO}_{3}(14 \mathrm{~N})$ and

$1640.1 \mathrm{ml} \mathrm{HClO}_{4}(12 \mathrm{~N})-$ for 4 days at $100{ }^{\circ} \mathrm{C}$. After evaporation of the acid mixture, $4 \mathrm{ml} \mathrm{HCl}$

165 acid $(6 \mathrm{~N})$ was added for 4 days at $100^{\circ} \mathrm{C}$. Once this had evaporated, the residue of the acid

166 dissolution was dissolved in $0.5 \mathrm{ml} \mathrm{HCl}(0.2 \mathrm{~N})$ and a sample aliquot (30ng of $\mathrm{Li}$ ) was placed

167 in a column containing cationic resin for Li separation. Blanks for the total digestion of the

168 solid samples by acids $\left(\mathrm{HF}, \mathrm{HNO}_{3}, \mathrm{HClO}_{4}\right.$ and $\left.\mathrm{HCl}\right)$ were less than $300 \mathrm{pg}$ of Li. Considering

169 a lithium concentration in the solid samples from 5 to $50 \mu \mathrm{g} . \mathrm{g}^{-1}$ and the sample quantity taken

170 for acid digestion ( $50 \mathrm{mg}$ ), it appears that the quantity of lithium ranges from 250 to $2500 \mathrm{ng}$.

171 Consequently, the blanks account for only 0.01 to $0.1 \%$ of the sample, which is negligible.

172 The accuracy and the reproducibility of the procedure for solid samples (dissolution +

173 purification procedure + mass analysis) were tested by repeated measurement of the JB-2

174 basalt standard (Geological Survey of Japan), giving a mean value of $\delta^{7} \mathrm{Li}=+4.9 \%$ $\pm 0.6(2 \sigma$,

$175 \mathrm{n}=17$ ) which is in good agreement with published values (see Carignan et al., 2007, and

176 Tomascak, 2004, for data compilation). Consequently, based on long-term measurements of

177 both seawater and JB-2 basalt standards, we estimate the external reproducibility of our

178 method to be around $\pm 0.5 \%$ o $(2 \sigma)$.

179

\section{4 - Results and comments}

Measured Li contents and $\mathrm{Li}$ isotopes for peat samples and fertilizers are reported in Tables 1

183 and 2, Table 3 reports ground- and surface-water data from the Narces de la Sauvetat

184 peatland, and Table 4 reports surface-water data from previous work. 


\subsection{Ground- and surface waters}

Lithium contents in the groundwater fluctuate strongly, between $0.014 \mu \mathrm{mol} \mathrm{L}^{-1}$ (S1, May 2007) and $28.260 \mu \mathrm{mol} \mathrm{L} \mathrm{L}^{-1}$ (Q2, July 2007) as shown in Table 3. Two different sets of Li contents are observed. The groundwaters in the peat bog display the highest content, over 1 $\mu$ mol L $\mathrm{L}^{-1}$, but the $\mathrm{Q} 2$ piezometer showed higher Li contents than the Q1 one. Spring waters generally display a lower Li content, around $0.015 \mu \mathrm{mol} \mathrm{L}^{-1}$ with the exception of S6 with a Li content of around $0.317 \mu \mathrm{mol} \mathrm{L}{ }^{-1}$. The surface water of the Fouragettes stream (R1) has a roughly constant $\mathrm{Li}$ content of around $0.4 \mu \mathrm{mol} \mathrm{L} \mathrm{L}^{-1}$, which corresponds to the lower value observed in streams draining the Massif Central, from volcanic catchments (Table 4) that have $\mathrm{Li}$ contents in the range 0.55 to $2.35 \mu \mathrm{mol} \mathrm{L} \mathrm{L}^{-1}$. Only the water of the Fouragettes (R1) stream agrees with the Li content in peat soil solution as reported by Pokrovsky et al. (2005, $0.22-0.34 \mu \mathrm{mol} \mathrm{L}{ }^{-1}$ ), while the groundwater Li content in the peat bog is higher by a factor around 10.

Lithium-isotope compositions $\left(\delta^{7} \mathrm{Li}, \%\right.$ ) are extremely variable in the site (Table 3$)$, ranging from $+12 \%$ ( R1, October 2007) up to $+1226 \%$,(Q2, May 2007). The Li-isotope composition at the peat bog outlet R1 fluctuated slightly during the survey period $(+12.0$ to $+13.1 \%$ ). Among the spring waters, S1 (+60.5\%o) and S5 (+47.1\%o) have a relatively high $\delta^{7} \mathrm{Li}$ while on the other hand, the S6 spring water has a slightly higher signature $(+15.1 \%$ o $)$ than that of the peat outlet $(+12$ to $+13.1 \%$ ond a lower signature than that of the rest of the spring waters. We suspect that the S6 spring may probably be connected to the surface water R1. Wastewater $(\mathrm{EU})$ has an enriched ${ }^{7} \mathrm{Li}$ value $\left(\delta^{7} \mathrm{Li}=+80.9 \%\right)$. In contrast to spring water and surface water, the groundwater in the peatland (Q1 and Q2) has singular $\delta^{7} \mathrm{Li}$ values, extremely enriched in ${ }^{7} \mathrm{Li}$, ranging from +961 to $+1111 \%$ for $\mathrm{Q} 1$ and from +1189 to $+1236 \%$, for Q2. Such high isotopic values occurred for high Li contents during the survey, around 
$4.26 \pm 1.96 \mu \mathrm{mol} \mathrm{L}^{-1}$ (mean value and standard deviation) for Q1 and an even higher mean 211 value in Q2 $\left(17.69 \pm 7.58 \mu \mathrm{mol} \mathrm{L}^{-1}\right)$.

212 The time variation of Li content from May 2007 to April 2008 is shown on Figure 2a. Both 213 Q1 and -Q2 show a significant decrease in Li content, though, where for Q2 the decrease is 214 continuous, for $\mathrm{Q} 1$ the $\mathrm{Li}$ contents showed an increase/steady-state/decrease pattern. 215 Conversely, there is no evidence of time variation in the Li content of the R1 surface water. 216 Figure $2 \mathrm{~b}$ illustrates the $\delta^{7} \mathrm{Li}$ variation during the same period and for the same sample set. Q2 217 varied little during the collection period with only $4 \%$ variation (between $\delta^{7} \mathrm{Li}=+1189$ to $218+1236 \%$ ), but the $\delta^{7} \mathrm{Li}$ for Q1 had a larger range, with a $14 \%$ variation (between $\delta^{7} \mathrm{Li}=+961$ to $+1111 \%$ ). The time variation in the Li isotope of the $\mathrm{R} 1$ surface water is low with only $8 \%$ variation (between $\delta^{7} \mathrm{Li}=+12.0$ to $13.1 \%$ ).

\subsection{The peat}

Six brown and black solid peat samples collected in the central part of the maar were analysed for Li content and Li isotopes (Table 1). Near piezometer Q1 (Fig. 1), the Li contents of the solid phase are low in the first two samples, at $0.8 \mu \mathrm{g} . \mathrm{g}^{-1}$ at $0-0.6 \mathrm{~m}$ and $1.9 \mu \mathrm{g} . \mathrm{g}^{-1}$ at $1 \mathrm{~m}$ depth, reaching $14.4 \mu \mathrm{g} . \mathrm{g}^{-1}$ at $2 \mathrm{~m}$ depth. Near piezometer Q2, the Li contents are higher and range from $9.8 \mu \mathrm{g} . \mathrm{g}^{-1}$ on surface up to $15.5 \mu \mathrm{g} . \mathrm{g}^{-1}$ at $0.3 \mathrm{~m}$ depth, showing a slight decrease at $1 \mathrm{~m}$ depth to $12.1 \mu \mathrm{g} . \mathrm{g}^{-1}$. Such Li contents in the peat are higher than those reported by Kamenov et al. (2009). The $\delta^{7} \mathrm{Li}$ values are close to $-1.1 \%$ near piezometer Q1 and show lower values near piezometer Q2, in the range of -0.4 to $+0.2 \%$.

\subsection{Bedrock, rainwaterand carbonaceous additives in fertilizers}

The lava is nepheline-normative basanite with $5-6 \mathrm{wt} \% \mathrm{Na}_{2} \mathrm{O}+\mathrm{K}_{2} \mathrm{O}$, to basalt (Villemant et al., 1981; Liotard et al., 1988). Recent Li-isotope data on volcanic rocks from the Massif

234 Central (Hamelin, 2008; Hamelin et al., 2009) reveal values from high $\delta^{7} \mathrm{Li}$ in basalt (+7\%o) to 
235 lower values in more evolved lava, with a $\delta^{7} \mathrm{Li}$ around $0 \%$ in trachyte with Li contents in the 236 range of 6-20 $\mu \mathrm{g} . \mathrm{g}^{-1}$.

237 For characterizing rainwater, we will consider the 15-month rainwater survey carried out in 238 the Massif Central (Négrel and Roy, 1998; Roy and Négrel, 2001) giving mean weighted Li 239 contents of around $0.05 \mu \mathrm{mol} \mathrm{L}{ }^{-1}$ and a mean weighted $\delta^{7} \mathrm{Li}$ of around $+25.4 \%$, $(\mathrm{n}=13$, Millot 240 et al., 2010c, d). It is worth noting that the mean weighted $\mathrm{Cl}$ and $\mathrm{Ca}$ contents of the rainwater 241 are respectively close to $19 \mu \mathrm{mol} \mathrm{L}{ }^{-1}$ and $16 \mu \mathrm{mol} \mathrm{L}^{-1}$ (Négrel and Roy, 1998).

242 Several additives used as fertilizers, such as carbonaceous additives or NPK, were analysed 243 during this study (Table 2). Carbonate amendment mainly consists of crushed carbonate and 244 carbonate-base (chalk or Mäerl), generally enriched in trace elements (mainly Zn and B). Soil 245 deficiency, because of the unavailability or exhaustion of metal ions, is very often the cause 246 of poor plant growth. In order to overcome these deficiencies, fertilizers with specific 247 chemical constituents in specific amounts are commonly added to soil, thus enriching the 248 growth medium. The fertilizers may be supplemented with certain trace elements, such as 249 copper, iron, manganese, zinc, cobalt, molybdenum and boron (Chen et al., 2010). Salts used 250 for B enrichment of carbonate amendments may also contain large amounts of Li. Many 251 enriched B-fertilizers use boron minerals, e.g. borax $\left(\mathrm{Na}_{2} \mathrm{~B}_{4} \mathrm{O}_{7}-10 \mathrm{H}_{2} \mathrm{O}\right.$, $)$ octoborate $252\left(\mathrm{Na}_{2} \mathrm{~B}_{8} \mathrm{O}_{13}-4 \mathrm{H}_{2} \mathrm{O}\right)$, or colemanite $\left.\left(\mathrm{CaB}_{3} \mathrm{O}_{4}(\mathrm{OH})_{3}-\mathrm{H}_{2} \mathrm{O}\right)\right)$ that are expected to contain some trace 253 elements such as lithium in the order of several tens to hundreds of $\mu \mathrm{g}$. $\mathrm{g}^{-1}$. However, there is 254 no evidence as yet that lithium is essential for plants. Both stimulating and toxic effects of 255 lithium have been noted in various crops (Bingham et al., 1964; McStay et al., 1980), and 256 some investigators have found that lithium in sprays and nutrient solutions produced 257 beneficial effects on certain plant diseases (Allender et al., 1997). For crushed carbonate, the 258 Li content ranges from 0.71 to $2.16 \mu \mathrm{g} . \mathrm{g}^{-1}$ (dry matter) and the $\delta^{7} \mathrm{Li}$ fluctuates between +2.10 259 and $+10.5 \%$. These $\delta^{7} \mathrm{Li}$ values fully agree with the ranges given by Coplen et al. (2002) for 
carbonates $(0-12 \%)$. For carbonate-base amendment, only one sample could be analysed 261 whose Li content was $0.17 \mu \mathrm{g} . \mathrm{g}^{-1}$ (dry matter), the $\delta^{7} \mathrm{Li}$ being significantly higher in ${ }^{7} \mathrm{Li}$ with a value high $\delta^{7} \mathrm{Li}$ of $215 \%$. In order to investigate this possibly enriched value for Caamendment, we first analysed a carbonate base, Mäerl, which is marine biological carbonate, and different additives (borax, Li-Cl, Li-B). The Mäerl sample has a marine signature of $+31 \%$ and only one additive was found to have an extremely ${ }^{7}$ Li-rich signature (hydroxide

${ }^{7} \mathrm{Li}$ monohydrate, $\delta^{7} \mathrm{Li}=+344000 \%$ ). Other additives, Li- and B-rich, have $\delta^{7} \mathrm{Li}$ values ranging between -16 and $+8 \%$. With only five tested additives, these results confirm high isotopic values as those over +2000 for Li-B reagents given by Qi et al. (1997).

\section{5 - Discussion}

\subsection{Origin of lithium in groundwaters}

The aim of the present discussion is to identify the different sources that can control lithium concentrations in groundwaters. Chloride is classically used as an atmospheric-input reference in many unpolluted hydrosystems (Meybeck, 1983; Sarin et al., 1989; Négrel, 1999), but Cl can also result from human activities such as domestic sewage, fertilizers, de-icing salts, etc.

277 (Sherwood, 1989). Generally, a high $\mathrm{Cl}$ content in surface- and ground-waters reflects human 278 influence. $\mathrm{Cl}$ concentrations in the different waters from the Sauvetat site ranged between 100 279 and $2000 \mu \mathrm{mol} \mathrm{L}{ }^{-1}$. The highest $\mathrm{Cl}$ content is found in spring waters $\left(2000 \mu \mathrm{mol} \mathrm{L} \mathrm{L}^{-1}\right)$, the 280 lowest in groundwater in the peatland $\left(100 \mu \mathrm{mol} \mathrm{L}^{-1}\right)$, but all are higher than the $\mathrm{Cl}$ content of 281 the rainwater that ranges between 20 and $40 \mu \mathrm{mol} \mathrm{L}^{-1}$ (Négrel and Roy, 1998).

282 Li shows a wide range of contents when plotted versus $\mathrm{Cl}$ (Fig. 3), all samples plotting with $283 \mathrm{Cl}$ and Li contents clearly higher than those of rainwater, with the exception of the surface 284 water and groundwater from the springs in the peatland that have Li contents similar to that of 285 rainwater. Compared to rainwater, there is evidence of $\mathrm{Cl}$ input without $\mathrm{Li}$ input for these 
samples, and it is very likely that this input may be related to fertilizers. For the groundwater

287 in the peat bog ( Q1 and Q2), the R1 surface water and the S6 spring water, there is another source of $\mathrm{Li}$ than rainwater without a large $\mathrm{Cl}$ input, as illustrated by the lack of a direct relationship between $\mathrm{Cl}$ and $\mathrm{Li}$ contents.

290 In addition, we can compare the Li with elements resulting from water-rock interaction such 291 as Na, a very soluble element in this process (Chetelat et al., 2005; Zakharova et al., 2007).

292 There is no relation between $\mathrm{Li}$ and $\mathrm{Na}$ contents (not shown), suggesting that Li enrichment 293 does not originate from the weathering of bedrock in this context. When plotted versus $\mathrm{Ca}$ (Fig. 4) and $\mathrm{HCO}_{3}$ (not shown), all water samples plot with Ca contents clearly different from rainwater (Ca range 1-80 $\mu$ mol: Négrel and Roy, 1998). Low Ca and Li contents are observed 296 for surface sample R1 that plots close to the S6 spring waters. On the contrary, higher Li-Ca$297 \mathrm{HCO}_{3}$ contents are observed for groundwater in the peatland, with a significant relationship 298 for $\mathrm{Q} 2$ between $\mathrm{Li}$ and $\mathrm{Ca}$, and between $\mathrm{HCO}_{3}$ and $\mathrm{Li}$ for Q1 and Q2. Additionally, the 299 relationship in Q2 groundwater shows the lowest contents for the winter and spring samples, 300 while the highest ones are for the summer samples. This indicates the existence of a common 301 source for $\mathrm{Li}-\mathrm{Ca}-\mathrm{HCO}_{3}$ in the Q1 and Q2 groundwaters, this source being more marked 302 during the summer season. The other spring- and waste-waters have low Li contents with 303 similar Ca contents, but lower $\mathrm{HCO}_{3}$ contents.

304 To conclude, we found an input into the peat system of $\mathrm{Ca}, \mathrm{HCO}_{3}$ and, noteworthy, $\mathrm{Mg}$, (not 305 shown) and an even larger one for Li. It is very likely that this input is related to the 306 application of carbonate amendments used for supplying $\mathrm{Ca}$ and $\mathrm{Mg}$ as the soils are too poor 307 for normal plant growth. More constraints will be added by the use of Li isotopes discussed 308 below. 
311 It is obvious that the Li-isotope signatures of the dissolved load in surface- and ground-waters

312 are not simply inherited from water/rock interactions and rainwater input, as suggested by the 313 graph showing $\delta^{7} \mathrm{Li}$ versus $\mathrm{Li}$ contents (Fig. 5). All surface- and ground-waters have $\delta^{7} \mathrm{Li}$ 314 values higher than that of the bedrock, in agreement with the preferential incorporation of ${ }^{6} \mathrm{Li}$ 315 in secondary minerals during basalt weathering as demonstrated by Pistiner and Henderson 316 (2003). The difference is generally between 5 and 15\%o and was corroborated by experimental 317 and field studies (Vigier et al., 2008, 2009, Millot et al. 2010a, b). The Li-isotope composition 318 in R1 surface water is quasi constant over time, which fully agrees with data for surface 319 waters as given by Huh et al. (1998) and Millot et al. (2010a) and references therein, but is 320 slightly higher than the signature of other rivers in the Massif Central $(+3.3$ to $+6.3 \%$, 321 Table 4). This constant signature is marked by a very low fluctuation of the Li content (mean 322 value and standard deviation of 0.39 and $0.04 \mu \mathrm{mol} \mathrm{L}^{-1}$, respectively). The S6 spring water 323 has a slightly higher signature than that of the R1 surface water $(+15.1 \%$ ) and a lower 324 signature than that of the rest of the spring waters. It is hydraulically not connected to the 325 peatland (same elevation as shown in Fig. 1) and its $\delta^{7} \mathrm{Li}$ is very close to that of the surface 326 water in the outlet, suggesting that groundwater like S6 may represent the largest input of 327 water to the river.

328 The rainwater was analysed for Li near Clermont-Ferrand, a few kilometers distant from this peat maar (Millot et al., 2010c), its range for $\delta^{7} \mathrm{Li}(+3$ to $+95 \%$ ) and $\mathrm{Li}$ content $(0.004-0.029$

$330 \mu \mathrm{mol} \mathrm{L}{ }^{-1}$ ) shown in Figure 5. Its contribution to the dissolved Li may be coherent with some 331 spring waters, even if the $\mathrm{Cl}$ content indicates a Cl-poor rain input (Fig. 3). The rainwater 332 contribution is negligible for the peat-groundwater system and seems minor for the S6 spring 333 water and the R1 surface water, agreeing with other surface waters collected in the Massif 334 Central (Table 4). 
335 The large increase in $\mathrm{Li}$ content and $\delta^{7} \mathrm{Li}$ in the peat groundwater can be a priori related to 336 two main different mechanisms. The first could be related to fractionation processes by 337 organic matter in the system, though biological uptake and vegetation recycling do not 338 significantly affect Li isotopes in the soil. The non-influence of litter degradation on Li339 isotope composition in soil is not surprising, as the Li concentration is a thousand times lower 340 in vegetation than in soil. Lemarchand et al. (2010) discussed a fractionation process by 341 organic matter that led to only a few tens \%o of fractionation for Li isotopes. It is thus unlikely

342 that the ${ }^{7} \mathrm{Li}$-rich values of groundwater could result from biological fractionation processes in 343 the system.

344 The second mechanism could be linked to a source effect with lithium enriched in ${ }^{7} \mathrm{Li}$. 345 Lithium-6 is valued as a source material for tritium production and as a neutron absorber in 346 nuclear fusion. Natural lithium contains about 7.5 percent lithium- 6 and large amounts of 347 lithium have been isotopically fractionated for use in nuclear weapons and thermonuclear fuel 348 stocks. Some of the material remaining from the production of lithium-6, which is depleted in 349 lithium-6 and enriched in lithium-7, is made commercially available, and some has been 350 released into the environment (Coplen et al., 2002). Depleted lithium-6 materials are 351 commonly available and the most enriched $\delta^{7} \mathrm{Li}$ values reported by Qi et al. (1997) are $352+3013 \%$ for a $\mathrm{Li}-\mathrm{OH}$ reagent and $+2333 \%$ for a $\mathrm{Li}_{2} \mathrm{~B}_{4} \mathrm{O}_{7}$ salt. We therefore propose that this 353 source effect may be related to the application of a carbonate amendment. This source is 354 represented in Figure 5 by the end-member EM1. We assume this end-member to represent 355 the required lithium content-Li isotope ratios to take all data into account (Négrel et al., 356 2010). When consisting of crushed carbonate this may impact the $\mathrm{Ca}$ and $\mathrm{HCO}_{3}$ budget of the 357 groundwater as well as the $\mathrm{pH}$, but also the Li budget as these amendments are artificially 358 enriched in trace elements. Soils contain trace elements (e.g. metal ions) in addition to other 359 macro- and micro-nutrients that are needed for plant growth. 
360 Analysis of chemical reagents and additives (Qi et al., 1997; Table 2) can show enriched $\delta^{7} \mathrm{Li}$

361 values, but among the analysed fertilizers in this study only one carbonate amendment has a 362 real enriched lithium value $\left(\delta^{7} \mathrm{Li}\right.$ over $\left.+200 \%\right)$, reflecting the addition of 7 -enriched $\mathrm{Li}$ in the 363 fertilizer manufacturing process, whose application may have an impact on the $\delta^{7}$ Li signature 364 of the groundwater.

365 First evidence of the impact of the carbonate amendment application is given by major ions. 366 Reporting data using Li-normalized ratios (in order to avoid concentration effects in Fig. 6 for $367 \mathrm{Ca} / \mathrm{Li}$ vs. $\mathrm{HCO}_{3} / \mathrm{Li}$ ) reveals trends between the peatland groundwater, the surface water and 368 the spring water that can be considered as mixing lines. Mixing of two solutions $(\mathrm{a}, \mathrm{b})$ with 369 different lithium-normalized ratios $\mathrm{X} / \mathrm{Li}\left(\mathrm{X}\right.$ being $\mathrm{Ca}$ and $\mathrm{HCO}_{3}$ in this case) will lead to a 370 mixed solution (i.e. "mix") that will have a X/Li ratio of:

$$
\mathrm{X} / \mathrm{Li}_{\text {mix }}=\mathrm{m} \mathrm{X} / \mathrm{Li}_{\mathrm{a}}+(1-\mathrm{m}) \mathrm{X} / \mathrm{Li}_{\mathrm{b}}
$$

372 where $\mathrm{X} / \mathrm{Li}_{\mathrm{a}}, \mathrm{X} / \mathrm{Li}_{\mathrm{b}}$ and $\mathrm{X} / \mathrm{Li}_{\text {mix }}$ are the lithium-normalized ratios for the solution mix from 373 two end-members a and $\mathrm{b}$, and $\mathrm{m}$ is the mixing proportion.

374 Two different mixing lines can then be calculated between the end-member EM1, 375 representing the application of carbonate amendment, the S6 spring water and other spring 376 waters. All groundwater samples from the peatland fall within these mixing lines, but EM1 377 has little impact on the surface waters as the samples deviate little from the S6 spring water. 378 The groundwater samples from the peatland clearly result from input of water from the spring 379 on the hill slope ("springs" in Fig. 6) inducing a dilution, the EM1 values reflecting 380 anthropogenic impact. However, the role of groundwater from the peatland on surface water 381 is not obvious when looking at the $\mathrm{X} / \mathrm{Li}$ ratios, and constraints on $\mathrm{Li}$ isotopes will help 382 deciphering the functioning of the area.

383 To summarize, we explain the extremely enriched ${ }^{7} \mathrm{Li}$ signature of the groundwaters in the 384 peat land by an external input due to Ca-amendment used in local agriculture. 


\subsection{Groundwater circulation}

Application of $\delta^{7} \mathrm{Li}$ ratios to peatland waters provides a unique perspective on the hydrogeochemical dynamics at the scale of this site. The groundwater from the peat (Q1 and Q2), being Li-rich and with extremely enriched $\delta^{7}$ Li values, seems to have no impact on the hydrologic budget from peat to the outlet (e.g. the Fouragettes stream). The $\delta^{7} \mathrm{Li}$ values of surface water (R1) are quasi constant throughout the survey, ranging between +12.0 and $+13.1 \%$, and moreover present non-enriched $\delta^{7} \mathrm{Li}$ values. Li-isotope contents in the peat system seem to vary due to a source effect and the groundwater in the peatland can be considered as a "spiked solution" that may, or may not, mix with the rest of the input (i.e. the spring waters) for which the river can be considered as the output.

The isotope systematics of two-component mixtures, described in detail by Faure (1986) and used for Sr isotopes by Hogan et al. (2000) for tracing peatland groundwater circulation, can be expressed as follows for Li isotopes and $\mathrm{X} / \mathrm{Li}$ ratios (Eq. 3). The mixed solution will have a $\delta^{7} \mathrm{Li}$ of:

$$
\delta^{7} \mathrm{Li}_{\text {mix }}=\left\{\left(\mathrm{X} / \mathrm{Li}_{\mathrm{a}} \times \delta^{7} \mathrm{Li}_{\mathrm{a}} \times \mathrm{m}\right) /\left(\mathrm{X} / \mathrm{Li}_{\text {mix }}\right)\right\}+\left\{\left(\mathrm{X} / \mathrm{Li}_{\mathrm{b}} \times \delta^{7} \mathrm{Li}_{\mathrm{b}} \times(1-\mathrm{m})\right) / \mathrm{X} / \mathrm{Li}_{\text {mix }}\right\}
$$

where $\mathrm{X} / \mathrm{Li}_{\mathrm{a}}, \mathrm{X} / \mathrm{Li}_{\mathrm{b}}$ and $\mathrm{X} / \mathrm{Li}_{\text {mix }}$ are the lithium normalized ratios for the solution mix from two end-members a and $\mathrm{b}, \delta^{7} \mathrm{Li}_{\mathrm{a}}, \delta^{7} \mathrm{Li}_{\mathrm{b}}$ and $\delta^{7} \mathrm{Li}_{\text {mix }}$ are the lithium isotope compositions, and $\mathrm{m}$ is the mixing proportion.

In Figure 7, the $\delta^{7} \mathrm{Li}$ versus $\mathrm{Ca} / \mathrm{Li}$ ratios are plotted together with two mixing lines calculated between the $\delta^{7} \mathrm{Li}$-enriched/Li-concentrated end-member (EM1) with a low $\mathrm{Ca} / \mathrm{Li}$ ratio and $\mathrm{S} 6$, and the S1 and S5. It can be seen that the mixing line between EM1 and S6 could not be invoked for explaining the range observed for Li isotopes of the peat groundwaters, as they fall within the EM1-S1 and S5 mixing line. However, the surface waters are not included in any mixing line as there is only weak variation in both the $\mathrm{Ca} / \mathrm{Li}$ ratio and $\delta^{7} \mathrm{Li}$ values. This result agrees with the functioning of the peatland, with water input from the hill area 
represented by $\mathrm{S} 1$ and $\mathrm{S} 5$ in addition to the impact of the amendment application. This

412 scheme induces dilution with a lower $\mathrm{Ca} / \mathrm{Li}$ ratio and $\delta^{7} \mathrm{Li}$ values during spring and winter

413 (Figs. 2, 4 and 5) in the peatland groundwater. There is no evidence of different pathways

414 using Li-isotope mixing plots and the peat system seems to be well mixed with regards to the

415 Li isotopes. In addition to showing mixing between EM1 and S1 and S5 waters, the mixing

416 plots also show that surface water at the outlet seems to be only controlled by the input of

417 groundwater like S6. The groundwater beneath the peatland has distinct ratios from that

418 which discharges into the stream; this strongly suggests that groundwater in the peatland does

419 not play any role in supplying surface-water runoff and may evolve as a stagnant system,

420 being only diluted as the contents (particularly Li) show.

\section{6 - Conclusions}

The results are described for lithium-isotope compositions of spring-, surface- and groundwater samples collected in a peat bog located in the French Massif Central in a maar depression.

Variations in $\delta^{7} \mathrm{Li}$ values can be used for distinguishing between precipitation, groundwater and anthropogenic inputs in peatlands, providing a unique perspective on the hydrologic dynamics of the system. The primary finding of this work concerns the existence of hugely enriched values for $\delta^{7} \mathrm{Li}$ in groundwater from the peatland. Mixing relationships indicate that most of the water in the peatland site derives from groundwater from the hill slope. Mixing plots also show that the surface water at the outlet seems to be only controlled by input from other groundwater bodies, and that groundwater in the peatland does not play any role in

434 supplying the surface water runoff and may evolve as a stagnant system.

435 This study highlights the possible role of Li isotopes as tracers of the surface- and ground436 water circulation in a wetland. When evaluating the transfer of water and/or solutes in a 
wetland, such complementary tracers of basic hydrogeology are highly important for constraining the system.

439 To conclude, the water within in the peatland exhibits very high $\delta^{7} \mathrm{Li}$ values consistent with

440 artificially enriched ${ }^{7} \mathrm{Li}$ associated with $\mathrm{Ca}$ amendments. This study opens a new field for Li 441 isotope investigations in hydro-systems and potential utility of $\mathrm{Li}$ isotopes as environmental 442 tracers.

\section{Acknowledgements}

445 This work was financially supported within the scope of the research partnership between BRGM, the 446 Haute Loire General Council and the Loire Bretagne Water Agency. This work benefited from the 447 collaboration of BRGM Chemistry laboratories for the major and trace elemental analyses: J.P. 448 Ghestem and T. Conte are thanked for their help, as well as M. Robert for her help in the Neptune 449 laboratory. We thank P. Tomascak and an anonymous reviewer for providing critical comments that 450 improved this manuscript. R. Rudnick is also thanked for editorial handling and constructive 451 comments. We are grateful to Dr. H.M. Kluijver for proofreading and editing the English text. 452 Financial support from the Région Centre is also acknowledged for the acquisition of the Neptune 453 MC-ICP-MS. This is BRGM contribution $\mathrm{n}^{\circ} 6409$.

\section{References}

455 Allender W.J., Cresswell G.C., Kaldor J., Kennedy I.R., 1997. Effect of lithium and lanthanum on 456 herbicide induced hormesis in hydroponically grown cotton and corn. J. Plant Nutr., 20.

457 Baird, A.J., 1995. Hydrological investigations of soil water and groundwater processes in wetlands. In 458 Hydrology and hydrochemistry of British wetlands, eds. J. Heathwaite and Hugues A.L., Wiley, 459 Chichester, 111-129

460 Bauer, I.E., Gignac, D., Vitt, D.H., 2003. Development of a peatland complex in boreal western 461 Canada: lateral site expansion and local variability in vegetation succession and long-term peat 462 accumulation. Can. J. Bot., 81, 833-847.

463 Bingham, F.T., Bradford, G.R., Page, A.L. 1964. Toxicity of Lithium. California Agriculture, 6-7. 464 Available at http://ucce.ucdavis.edu/files/repositoryfiles/ca1809p6-65239.pdf. 
Boivin, P., Gourgaud, A., 1978. Synchronism of maar- and stromboli-type eruptions in La Sauvetat, southern Deves, French Central Massif. C.R. Soc. Geol. Fr. 45, 25-39.

Bragg, O.M., 2002. Hydrology of peat-forming wetlands in Scotland. Sci. Tot. Env. 294, 111-129.

Brenot, A., Négrel, Ph., Millot, R., Bertin, C., Deciphering groundwater circulation in a peatland by multi-isotope tracing. Submitted to Appl. Geochem.

Brousse, R., Lefevre, C., 1990. Le volcanisme en France et en Europe limitrophe. Masson ed., 262 p.

Bullock, A., Acreman, M. 2003. The role of wetlands in the hydrological cycle. Hydrol. Earth System Sci. 7, 358-389.

Carignan, J., Vigier, N., Millot, R., 2007. Three secondary reference materials for Li isotopic measurements: 7Li-N, 6Li-N and LiCl-N. Geostandards and Geoanalyt. Res., 31, 7-12.

Chen, W. Chang, A.C. Wu, L. Page, A.L. Koo B. 2010. Trace elements in biosolids-amended soils. DOI 10.1002/9781444319477.ch6. In Trace Elements in Soils, P.S. Hooda ed. DOI: 10.1002/9781444319477. Blackwell Publishing Ltd

Chetelat, B., Gaillardet, J., 2005. Boron isotopes in the Seine River, France: A probe of anthropogenic contamination. Environ. Sci. Technol. 39, 2486-2493.

Coplen, T.B., Hopple, J.A., Böhlke, J.K., Peiser, H.S., Rieder, S.E., Krouse, H.R., Rosman, K.J.R., Ding, T., Vocke, R.D. Jr., Révész, K.M., Lamberty, A., Taylor, P., De Bièvre, P., 2002. Compilation of minimum and maximum isotope ratios of selected elements in naturally occurring terrestrial materials and reagents. U.S. Geological Survey, Water-Resources Investigations, Report 01-4222.

Cubizolle, H., Bonnel, P., Oberlin, C., Tourman, A., Porteret, J., 2007. Advantages and limits of radiocarbon dating applied to peat inception during the end of the late glacial and the Holocene: the example of mires in the eastern Massif Central (France). Quaternaire 18, 187-206.

Falkner, K.K., Church, M., Measures, C.I., LeBaron ,G., Thouron, D., Jeandel, C., Stordal, M.C., Gill, G.A., Mortlock, R., Froelich, P., Chan, L.H. 1997. Minor and trace element chemistry of Lake Baikal, its tributaries, and surrounding hot springs. Limnology and Oceanography 42, 329-345.

Francez, A.J., Bignon, J.J., Mollet, A.M., 1992. The peatlands in France: localization, characteristics, use and conservation. Suo. Mires and Peat 43, 11-24.

Hamelin, C., 2008. Géochimie isotopique du lithium dans les basaltes : géochimie des MORBs du Pacifique Sud. PhD Thesis, University of Bretagne Occidentale, $184 \mathrm{p}$.

Hamelin, C., Seitz, H.M., Barrat, J.A., Dosso, L., Maury, R.C., Chaussidon, M., 2009. A low $\delta^{7} \mathrm{Li}$ lower crustal component: evidence from an alkalic intraplate volcanic series (Chaîne des Puys, French Massif Central). Chem. Geol. 266, 205-217.

Hill, B.M., Siegel, D.I., 1991. Groundwater-flow and the metal content of peat. J. of Hydrol. 123, 211224. 
Hogan, J.F., Blum, J.D., Siegel, D.I., Glaser, P.H., 2000. ${ }^{87} \mathrm{Sr} /{ }^{86} \mathrm{Sr}$ as a tracer of groundwater discharge and precipitation recharge in the Glacial Lake Agassiz peatlands, northern Minnesota. Wat. Res. Res. 36, 3701-3710.

Hogan J.F., Blum J.D. (2003) Boron and lithium isotopes as groundwater tracers: a study at the Fresh Kills Landfill, Staten Island, New York, USA. Applied Geochemistry, 18, 615-627.

Huh, Y., Chan, L.C., Zhang, L., Edmond, J.M., 1998. Lithium and its isotopes in major world rivers: implications for weathering and the oceanic budget. Geochim. Cosmochim. Acta 62, 2039-2051.

Huh, Y., Chan, L.C., Edmond, J.M., 2001. Lithium isotopes as a probe of weathering processes: Orinoco River. Earth Planet.Sci. Lett., 194, 189-199.

Hunt, R.J., Bullen, T.D., Krabbenhoft, D.P., Kendall, C., 1998. Using stable isotopes of water and strontium to investigate the hydrology of a natural and a constructed wetland. Groundwater 36, 434-443.

Kamenov, G.D., Brenner, M., Tucker, J.L., 2009. Anthropogenic versus natural control on trace element and $\mathrm{Sr}-\mathrm{Nd}-\mathrm{Pb}$ isotope stratigraphy in peat sediments of southeast Florida (USA), similar to 1500 AD to present. Geochim. Cosmochim. Acta 73, 3549-3567.

Kisakürek, B., Widdowson, M., James, R.H., 2004. Behaviour of Li isotopes during continental weathering: the Bidar laterite profile, India. Chem. Geol., 212, 27-44.

Kisakürek, B., James, R.H., Harris, N.B.W., 2005. Li and $\delta^{7} \mathrm{Li}$ in Himalayan rivers: Proxies for silicate weathering? Earth Planet.Sci. Lett., 237, 387-401.

Lappalainen, E., 1996. General review on world peatland and peat resources. In Global Peat Resources, ed. E. Lappalainen, International Peat Society, Finland, 53-56.

Lemarchand, E. Chabaux, F. Vigier, N. Millot, R. Pierret M.C., 2010 Lithium isotopic behaviour in a forested granitic catchment (Strengbach, Vosges Mountains, France). Geochim. Cosmochim. Acta, doi: 10.1016/j.gca.2010.04.057.

Liotard, J.M., Briot, D., Boivin, P., 1988. Petrological and geochemical relationships between pyroxene megacrysts and associated alkali-basalts from Massif Central (France). Contrib. Mineral. Petrol. 98, 81-90

McStay, N.G., Rogers, H.H. Anderson, C.E. 1980. Effects of lithium on Phaseolus vulgaris L. The Science of The Total Environment 16, 185-191.

Meybeck, M., 1983. Atmospheric inputs and river transport of dissolved substances. IAHS Publication $141,173-192$.

Meybeck, M., 1986. Composition chimique des ruisseaux non pollués de France. Sci. Geol. Bull. 39, 3-77.

Michon, L., Merle, O., 2001. The evolution of the Massif Central Rift; spatio-temporal distribution of the volcanism. Bull. Soc. Géol. Fr. 172, 201-211.

Millot, R., Guerrot, C., Vigier, N., 2004. Accurate and high precision measurement of lithium isotopes in two reference materials by MC-ICP-MS. Geostandards and Geoanalytical Res., 28, 153-159. 
Millot, R., Négrel, Ph., 2007. Multi-isotopic tracing $\left(\delta^{7} \mathrm{Li}, \delta^{11} \mathrm{~B},{ }^{87} \mathrm{Sr} /{ }^{86} \mathrm{Sr}\right)$ and chemical geothermometry: evidence from hydro-geothermal systems in France. Chem. Geol. 244, 664-678.

Millot, R., Vigier, N., Gaillardet, J., 2010a. Behaviour of lithium and its isotopes during weathering in the Mackenzie Basin, Canada. Geochim. Cosmochim. Acta, doi:10.1016/j.gca.2010.04.057.

Millot, R., Scaillet, B., Sanjuan, B., 2010b Lithium isotopes in island arc geothermal systems: Guadeloupe, Martinique (French West Indies) and experimental approach. Geochim. Cosmochim. Acta. 74, 1852-1871.

Millot, R., Guerrot, C., Petelet-Giraud, E., Négrel, Ph., 2010c. Multi-isotopic composition $\left(\delta^{7} \mathrm{Li}-\delta^{11} \mathrm{~B}-\right.$ $\left.\delta \mathrm{D}-\delta^{18} \mathrm{O}\right)$ of rainwaters in France: origin and spatio-temporal characterization. Appl. Geochem, in revision.

Millot, R., Petelet-Giraud E., Guerrot, C., Négrel Ph. 2010d. Lithium and Boron isotopic compositions of rainwaters in France: origin and spatio-temporal characterization. Geophysical Research Abstracts, Vol. 12, EGU2010-9744, 2010, EGU General Assembly 2010.

Négrel, Ph., 1999. Geochemical study of a granitic area - The Margeride Mountains, France: chemical element behavior and ${ }^{87} \mathrm{Sr} /{ }^{86} \mathrm{Sr}$ constraints. Aqu. Geochem. 5, 125-165.

Négrel, Ph., Roy S., 1998. Chemistry of rainwater in the Massif Central (France): a strontium isotope and major element study. Appl. Geochem. 13, 941-952.

Négrel, Ph., Petelet-Giraud, E., Sgouridis F., 2005. Significance of wetlands in the water cycle. In EUROWET, Integration of European Wetland research in sustainable management of the water cycle. Available at http://eurowet.brgm.fr, 22 p.

Négrel, Ph., Petelet-Giraud, E. 2005. Strontium isotope as tracers of groundwater-induced floods: the Somme case study (France). Journal of Hydrology, 305, 99-119.

Négrel, Ph., Millot, R., Roy, S., Guerrot, C., Pauwels, H., 2010. Lead isotopes in groundwater as an indicator of water rock interaction (Masheshwaram catchment, Andhra Pradesh, India). Chemical Geology, doi: 10.1016/j.chemgeo.2010.03.012.

Pistiner, J.S., Henderson, G.M., 2003. Lithium isotope fractionation during continental weathering processes. Earth Planet.Sci. Lett., 214, 327-339.

Pogge von Strandmann, P.A.E., Burton, K.W., James, R.H., van Calsteren, P., Gislason, S.R., Mokadem, F., 2006. Riverine behaviour of uranium and lithium isotopes in an actively glaciated basaltic terrain. Earth Planet.Sci. Lett. 251, 134-147.

Pokrovsky, O.S., Dupré, B., Schott, J., 2005. Fe-Al-organic colloids control of trace elements in peat soil solutions: Results of ultrafiltration and dialysis. Aqu. Geochem. 11, 241-278.

Qi, L.H., Coplen, T.B., Wang, Q.Z., Wang, Y.H., 1997. Unnatural isotopic composition of lithium reagents. Anal. Chem 69, 4076-4078.

Roy, S., Négrel, Ph., 2001. A Pb isotope and trace element study of rainwater from the Massif Central (France). Sci. Tot. Env., 277, 225-239. 
Sarin, M.M., Krishnaswami, S., Dilli, K., Somayajulu, B.L., Moore, W.S., 1989. Major ion chemistry of the Ganga-Brahmaputra river system: Weathering processes and fluxes to the Bay of Bengal. Geochim. Cosmochim. Acta 53, 997-1009.

Sherwood, W.C., 1989. Chloride loading in the South Fork of the Shenandoah River, Virginia, U.S.A. Environ. Geol. Wat. Sci. 14, 99-106.

Shotyk, W., 1988. Review of the inorganic geochemistry of peats and peatland waters. Earth Sci. Rev. 25, 95-176.

Skalbeck, J.D., Reed, D.M., Hunt, R.J., Lambert J.D., 2009. Relating groundwater to seasonal wetlands in southeastern Wisconsin, USA. Hydrogeol. J.17, 215-228.

Teng, F.Z., McDonough, W.F., Rudnick, R.L., Dalpé, C., Tomascak, P.B., Chappell, B.W., Gao, S., 2004. Lithium isotopic composition and concentration of the upper continental crust. Geochim. Cosmochim. Acta 68, 4167-4178.

Tomascak, P.B., 2004. Developments in the understanding and application of lithium isotopes in the earth and planetary sciences. Rev. Mineral. \& Geochem., 55, 153-195.

Tourman, A., 2007. Fonctionnement, dynamique et intérêt paléoenvironnemental des tourbières du plateau volcanique du Devès (Velay, Massif Central français). PhD thesis, University of SaintEtienne, 373 p.

Vigier, N., Decarreau, A., Millot, R., Carignan, J., Petit, S., France-Lanord, C., 2008. Quantifying Li isotope fractionation during smectite formation and implications for the Li cycle. Geochim. Cosmochim. Acta 72, 780-792.

Vigier, N., Gislason, S.R., Burton, K.W., Millot, R., Mokadem, F., 2009. The relationship between riverine lithium isotope composition and silicate weathering rates in Iceland. Earth Planet.Sci. Lett., doi:10.1016/j.eps1.2009.08.026.

Villemant, B., Joron, J.L., Jaffrezic, H., Treuil, M., 1981. Distribution coefficients of major and trace elements: fractional crystallization in the alkali basalt series of Chaîne des Puys, Massif Central, France. Geochim. Cosmochim. Acta 45, 1997-2016.

Wheeler, B.D., Shaw, S.C., Fojt, W.F., Allan Robertson, R., 1995. Restoration of temperate wetlands. Wiley, Chichester.

Wilson, M., Downes, H., 1991. Tertiary-Quaternary extension-related alkaline volcanism in western and central Europe. J. Petrol. 32, 811-849.

Woodland, A.B., Jugo, P.J., 2007. A complex magmatic system beneath the Devès volcanic field, Massif Central, France: evidence from clinopyroxene megacrysts. Contributions to Mineralogy and Petrology 153, 719-731.

Zakharova, E.A., Pokrovsky, O.S., Dupré, B., Gaillardet, J., Efimova, L.E., 2007. Chemical weathering of silicate rocks in Karelia region and Kola peninsula, NW Russia: Assessing the effect of rock composition, wetlands and vegetation. Chem. Geol. 242, 255-277. 


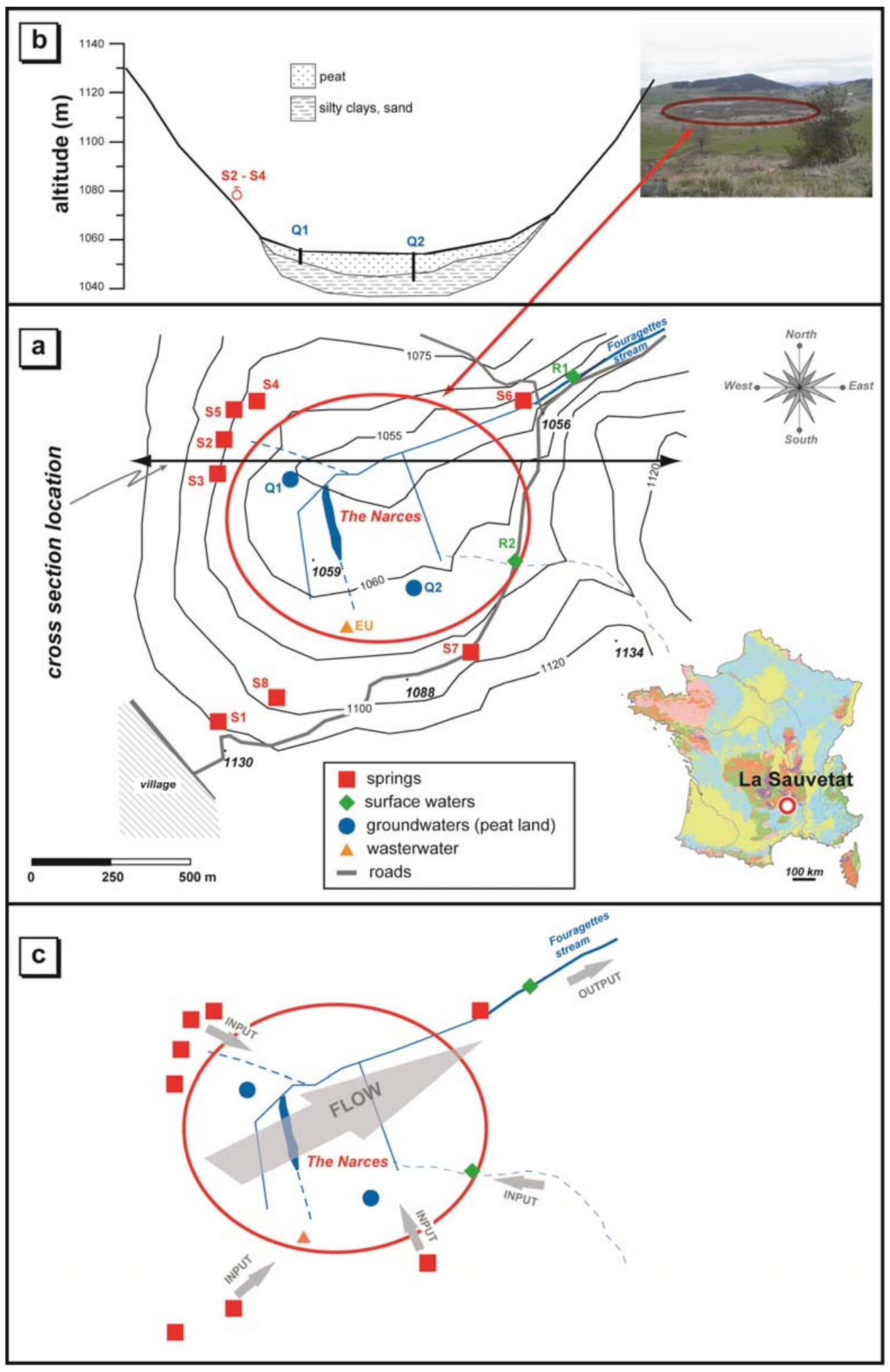

611 Figure 1. Location of the Narces de la Sauvetat peatland in the Massif Central (France). 612 Simplified topographic map of the peatland with location of boreholes, springs and surface 613 water identified on the site. 

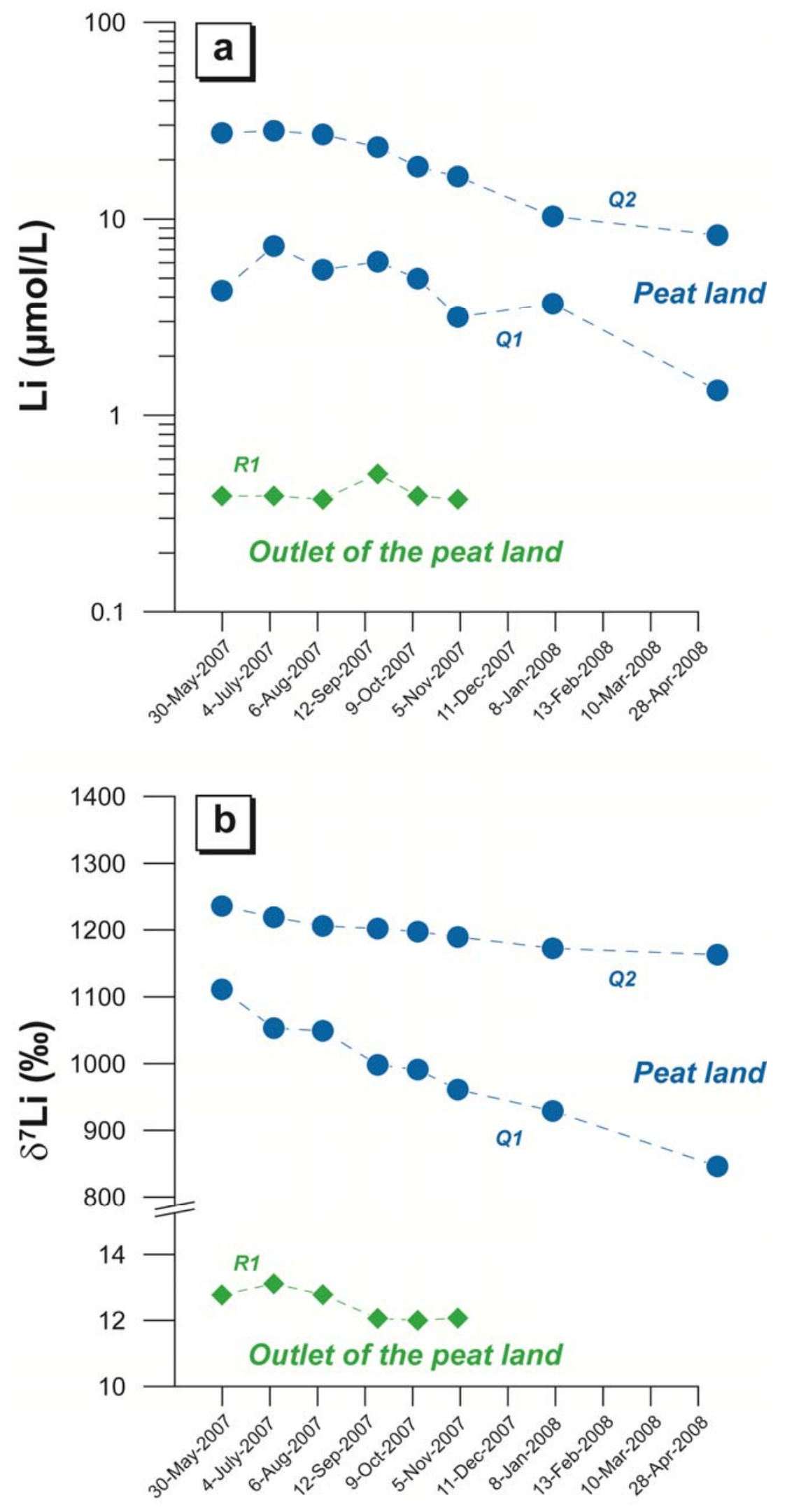

615 Figure 2. Time evolution between May 2007 and April 2008 of the Li concentration ( $\mu$ mol. $\mathrm{L}^{-}$ $61{ }^{{ }^{1}}$ ) and $\delta^{7} \mathrm{Li}$ in groundwater from the peatland $(\mathrm{Q} 1$ and $-\mathrm{Q} 2)$ and surface water $(\mathrm{R} 1)$ of the 617 Fouragettes stream, the outlet of the Narces de la Sauvetat peatland. 


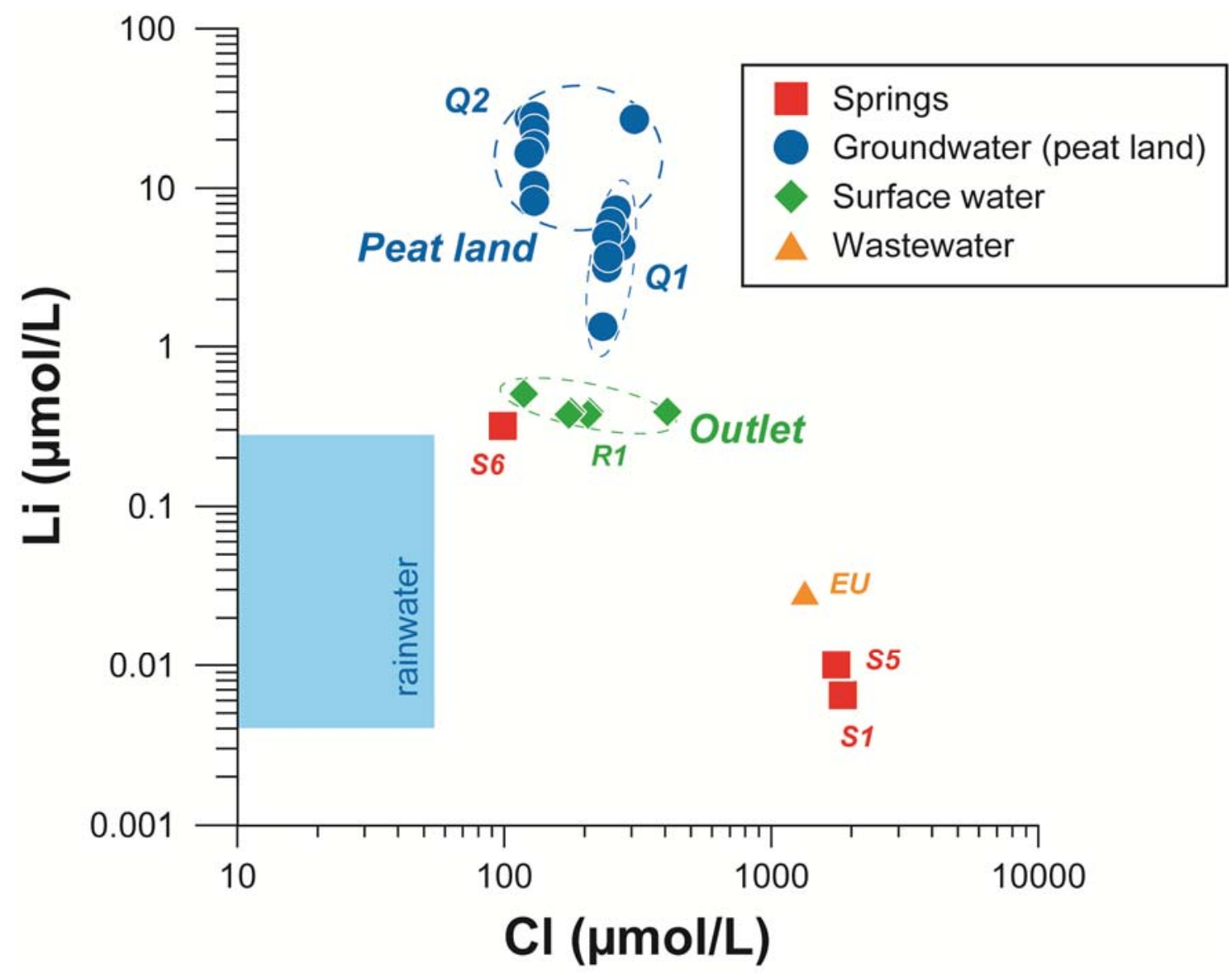

\section{8}

619

Figure 3. Li $\left(\mu \mathrm{mol} . \mathrm{L}^{-1}\right)$ vs. $\mathrm{Cl}\left(\mu \mathrm{mol} . \mathrm{L}^{-1}\right)$ diagram for groundwater from the peatland (Q1 and 620 -Q2), spring water S1 and S5 located on the hillslope on the western side and S6 (emerging close to the outlet of the area), wastewater EU and surface water R1 in the Narces de la 622 Sauvetat peatland. Rainwater field from the Massif Central is also indicated (Millot et al., 2010c, d, see text). 


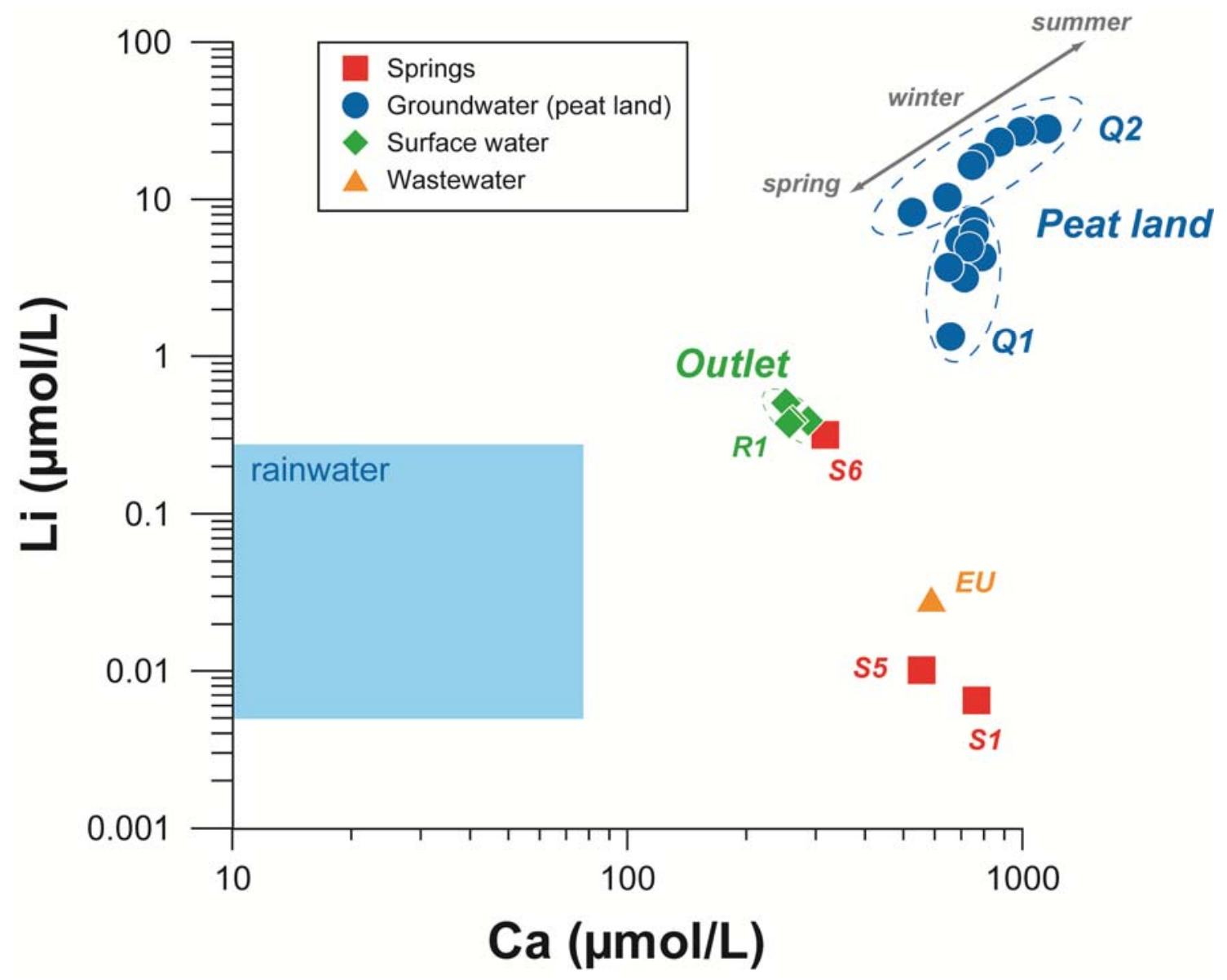

624

Figure 4. $\mathrm{Li}\left(\mu \mathrm{mol} . \mathrm{L}^{-1}\right)$ vs. $\mathrm{Ca}\left(\mu \mathrm{mol} . \mathrm{L}^{-1}\right)$ diagram for groundwater from the peatland $(\mathrm{Q} 1$

626 and Q2), spring waters S1 and S5 located on the hillslope on the western side and S6

627 (emerging close to the outlet of the area), wastewater EU and surface water R1 in the

628 Narces de la Sauvetat peatland. Arrow shows the evolution of Q2 groundwater in the

629 peatland as a function of the season. Rainwater field from the Massif Central are also

630 indicated (Millot et al., 2010c, d, see text). 


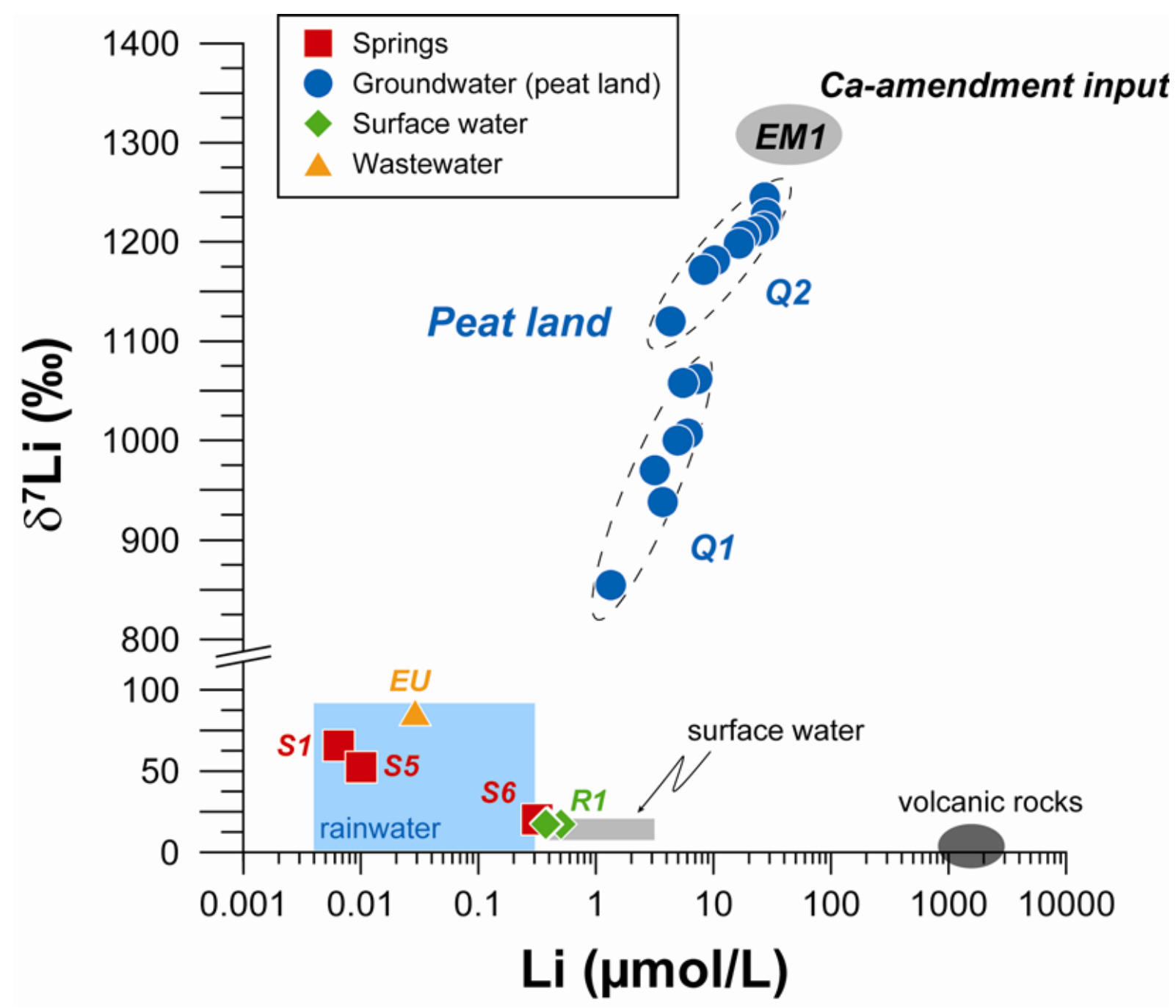

Figure 5. Plot of $\delta^{7} \mathrm{Li}$ vs. Li concentration $\left(\mu \mathrm{mol} . \mathrm{L}^{-1}\right)$ for groundwater from the peatland (Q1 633 and -Q2), spring water S1 and S5 located on the hillslope on the western side and S6 634 (emerging close to the outlet of the area), wastewater EU and surface water R1 in the 635 Narces de la Sauvetat peatland. Rainwater, volcanic rocks and surface water from the 636 Massif Central are also indicated (see text). The end-member EM1 corresponds to the 637 carbonate amendment input. Its location on the graph is assumed to represent the required 638 lithium content-Li isotope ratios to take all data into account. 


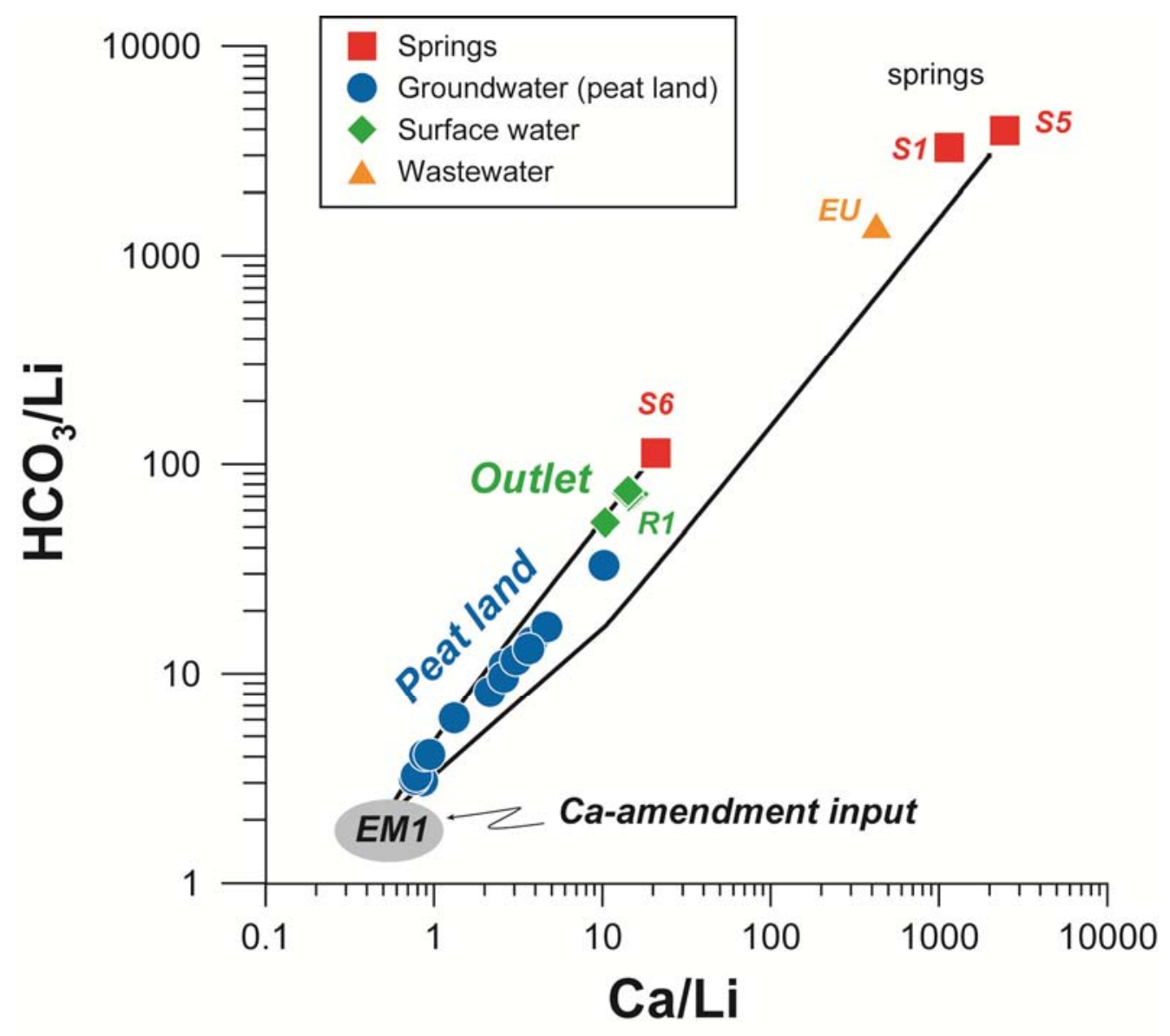

639

Figure 6. Plot of $\mathrm{HCO}_{3} / \mathrm{Li}$ vs. $\mathrm{Ca} / \mathrm{Li}$ ratios for groundwater from the peatland (Q1 and -Q2),

641 spring water S1 and S5 located on the hillslope on the western side and S6 (emerging close

642 to the outlet of the area), wastewater EU and surface water R1 in the Narces de la Sauvetat

643 peatland. The end-member EM1 corresponds to the carbonate amendment input. Its

644 location on the graph is assumed to represent the required $\mathrm{Ca} / \mathrm{Li}$ and $\mathrm{HCO}_{3} / \mathrm{Li}$ ratios to take

645 all data into account. Two different mixing lines can then be calculated between the end-

646 member EM1, representing the application of carbonate amendment, the S6 spring water

647 and other spring waters (see text). 


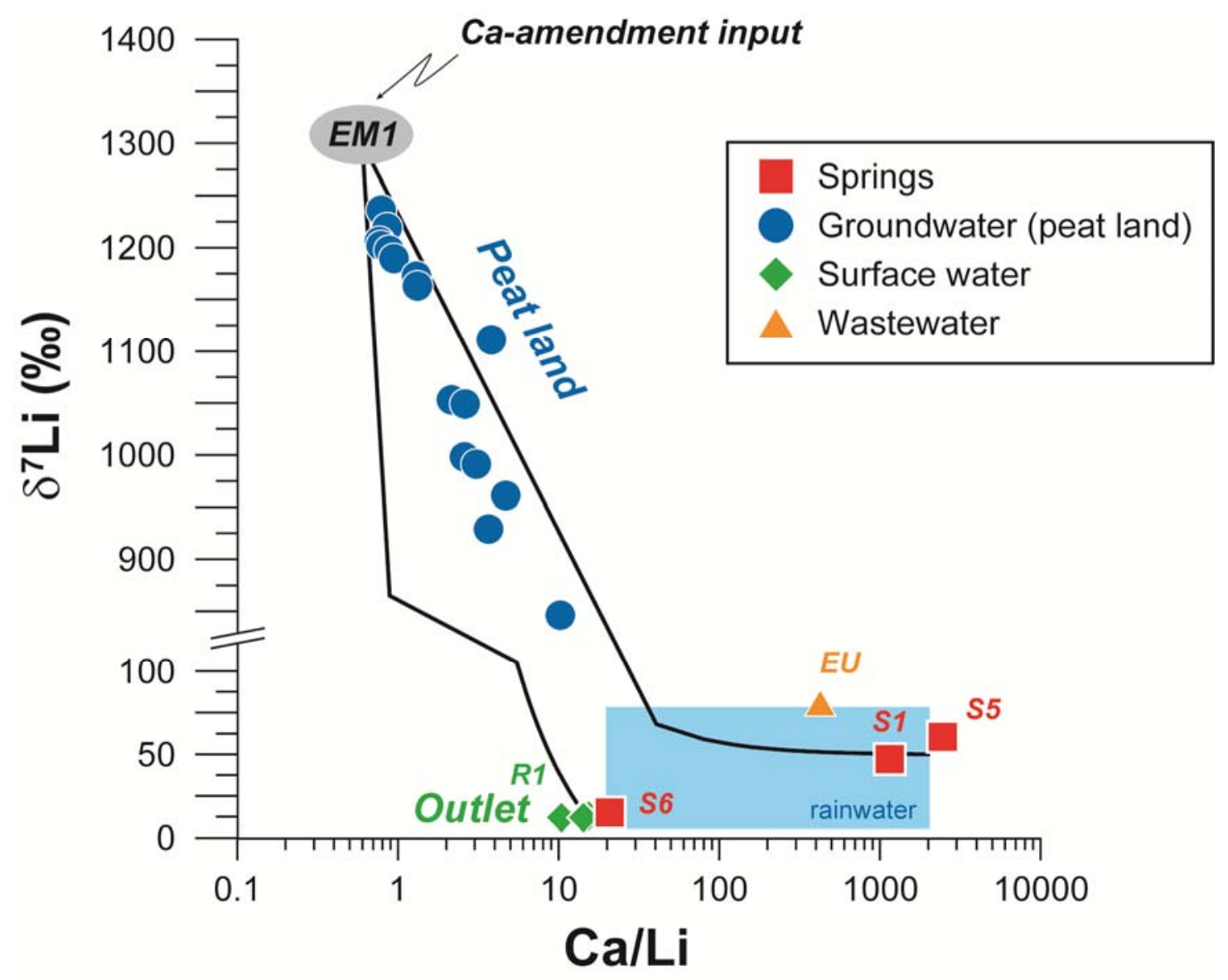

Figure 7. Plot of $\delta^{7} \mathrm{Li}$ vs. $\mathrm{Ca} / \mathrm{Li}$ ratios for groundwater from the peatland (Q1 and -Q2), spring water S1 and S5 located on the hillslope on the western side and S6 (emerging close to the outlet of the area), wastewater EU and surface water R1 in the Narces de la Sauvetat peatland. The end-member EM1 corresponds to the carbonate amendment input. Its location on the graph is assumed to represent the required $\mathrm{Ca} / \mathrm{Li}$ and $\mathrm{Li}$ isotope ratios to take all data into account. Two different mixing lines can then be calculated between the end-member EM1, representing the application of carbonate amendment, the S6 spring water and other spring waters (see text). 
666

667

668 Table 1. Results of $\mathrm{Li}$ concentration $\left(\mu \mathrm{g} . \mathrm{g}^{-1}\right)$ and $\delta^{7} \mathrm{Li}$ in the peat samples collected at 669 different depths $(\mathrm{Z}$ in $\mathrm{m})$ in the Narces de la Sauvetat peatland.

670

Table 2. Results of $\mathrm{Li}$ concentration $\left(\mu \mathrm{g} . \mathrm{g}^{-1}\right)$ and $\delta^{7} \mathrm{Li}$ in various fertilizers and additives.

\begin{tabular}{|c|c|c|c|}
\hline Sample & Composition & Li & $\delta^{7} \mathrm{Li}$ \\
\hline & & $\mu \mathrm{g} \cdot \mathrm{g}^{-1}$ & $\%$ \\
\hline \multicolumn{4}{|l|}{ Fertilizers } \\
\hline MEAC & crushed carbonate & 1.14 & 2.85 \\
\hline Jardidol & enriched carbonate & 0.17 & 215 \\
\hline AMD & crushed carbonate & 2.16 & 2.10 \\
\hline Carbocentre & crushed carbonate & 0.71 & 10.50 \\
\hline BB600 & NPK & 1.08 & 23.10 \\
\hline MEAC2 & NPK & 1.75 & 12.90 \\
\hline \multicolumn{4}{|l|}{ Additives } \\
\hline MAËRL & Marine carbonate & 2.68 & 31.03 \\
\hline BORAX pentahydrate NEOBOR & Borax & 13.16 & 4.96 \\
\hline BORAX decahydrate GRANULE & Borax & 7.43 & -16.05 \\
\hline Lithium Chloride & $\mathrm{Li}-\mathrm{Cl}$ & 115.26 & 0.05 \\
\hline $\mathrm{Li}_{2} \mathrm{~B}_{4} \mathrm{O}_{7}$ & Li-B & 19.97 & 8.18 \\
\hline Hydroxyde ${ }^{7}$ Li monohydrate & $\mathrm{Li}$ & 138.47 & 344000 \\
\hline
\end{tabular}

674

675

676

677

678

679

680

681

682

683

684

685

686

687

688

\begin{tabular}{cccccc} 
Sample & $\mathbf{X}$ & $\mathbf{Y}$ & $\mathbf{Z}$ & $\mathbf{L i}$ & $\boldsymbol{\delta}^{\mathbf{7}} \mathbf{L i}$ \\
\hline & & & $\mathrm{m}$ & $\mu \mathrm{g} \cdot \mathrm{g}^{-1}$ & $\%$ \\
Q1 0-60 & 720157 & 1985198 & 0 & 0.84 & -0.92 \\
Q1 1 & 720157 & 1985198 & 1 & 1.9 & -10.97 \\
Q1 2 & 720157 & 1985198 & 2 & 14.36 & -0.74 \\
Q2surf & 720542 & 1984852 & 0 & 9.83 & -0.16 \\
Q2 30 & 720542 & 1984852 & 0.3 & 15.51 & 0.29 \\
Q2 1 & 720542 & 1984852 & 1 & 12.05 & 0.04
\end{tabular}


689

\begin{tabular}{|c|c|c|c|c|c|c|c|c|c|c|}
\hline Sample & Date & $x$ & $\mathbf{Y}$ & $\mathrm{Cl}$ & $\mathrm{Ca}$ & $\mathrm{Na}$ & $\mathrm{Mg}$ & $\mathrm{HCO} 3$ & $\mathbf{L i}$ & $\delta^{7} \mathrm{Li}$ \\
\hline & & & & $\mu \mathrm{mol}_{-1} \mathrm{~L}$ & $\mu \mathrm{mol} . \mathrm{L}^{-1}$ & $\mu \mathrm{mol}_{1}$ & $\mu \mathrm{mol} . \mathrm{L}^{-1}$ & $\mu \mathrm{mol} . \mathrm{L}^{-1}$ & $\mu \mathrm{mol} . \mathrm{L}^{-1}$ & $\%$ \\
\hline \multicolumn{11}{|c|}{ Groundwater } \\
\hline Q1 & 30-mai-07 & 720157 & 1985198 & 273 & 791 & 200 & 852 & 2951 & 4.322 & 1111.0 \\
\hline Q1 & 04-juil-07 & 720157 & 1985198 & 262 & 753 & 200 & 840 & 2869 & 7.290 & 1053.0 \\
\hline Q1 & 06-août-07 & 720157 & 1985198 & 259 & 693 & 222 & 852 & 2918 & 5.518 & 1049.0 \\
\hline Q1 & 12 -sept-07 & 720157 & 1985198 & 251 & 756 & 200 & 831 & 2803 & 6.065 & 998.0 \\
\hline Q1 & 09-oct-07 & 720157 & 1985198 & 242 & 733 & 200 & 790 & 2787 & 4.970 & 991.0 \\
\hline Q1 & 05-nov-07 & 720157 & 1985198 & 242 & 713 & 196 & 815 & 2557 & 3.170 & 961.0 \\
\hline Q1 & 08-janv-08 & 720157 & 1985198 & 245 & 651 & 178 & 737 & 2344 & 3.703 & 929.0 \\
\hline Q1 & 28-avr-08 & 720157 & 1985198 & 234 & 658 & 196 & 794 & 2131 & 1.340 & 846.1 \\
\hline Q2 & 30-mai-07 & 720542 & 1984852 & 124 & 1035 & 378 & 1181 & 4164 & 27.374 & 1236.0 \\
\hline Q2 & 04-juil-07 & 720542 & 1984852 & 130 & 1155 & 313 & 1267 & 4147 & 28.094 & 1219.0 \\
\hline Q2 & 06-août-07 & 720542 & 1984852 & 307 & 990 & 296 & 1082 & 4049 & 26.913 & 1206.0 \\
\hline Q2 & 12 -sept-07 & 720542 & 1984852 & 130 & 875 & 265 & 909 & 3623 & 23.196 & 1202.0 \\
\hline Q2 & 09-oct-07 & 720542 & 1984852 & 130 & 781 & 256 & 811 & 3606 & 18.441 & 1197.5 \\
\hline Q2 & 05-nov-07 & 720542 & 1984852 & 124 & 746 & 248 & 786 & 3246 & 16.453 & 1189.4 \\
\hline Q2 & 08-janv-08 & 720542 & 1984852 & 130 & 646 & 248 & 733 & 3033 & 10.316 & 1172.5 \\
\hline Q2 & 28-avr-08 & 720542 & 1984852 & 130 & 526 & 226 & 597 & 2443 & 8.284 & 1163.0 \\
\hline \multicolumn{11}{|l|}{$\begin{array}{c}\text { Surface } \\
\text { water }\end{array}$} \\
\hline $\mathrm{R} 1$ & 30-mai-07 & 721052 & 1985500 & 208 & 259 & 374 & 366 & 1361 & 0.389 & 12.8 \\
\hline $\mathrm{R} 1$ & 04-juil-07 & 721052 & 1985500 & 408 & 287 & 422 & 395 & 1344 & 0.389 & 13.1 \\
\hline R1 & 06-août-07 & 721052 & 1985500 & 206 & 257 & 330 & 346 & 1262 & 0.375 & 12.8 \\
\hline $\mathrm{R} 1$ & $12-$ sept-07 & 721052 & 1985500 & 118 & 252 & 348 & 309 & 1279 & 0.504 & 12.1 \\
\hline $\mathrm{R} 1$ & 09-oct-07 & 721052 & 1985500 & 177 & 262 & 357 & 329 & 1361 & 0.389 & 12.0 \\
\hline $\mathrm{R} 1$ & 05-nov-07 & 721052 & 1985500 & 175 & 257 & 352 & 342 & 1344 & 0.375 & 12.1 \\
\hline \multicolumn{11}{|l|}{$\begin{array}{l}\text { Spring } \\
\text { water }\end{array}$} \\
\hline S1 & 06-août-07 & 719929 & 1984414 & 1854 & 766 & 426 & 728 & 1230 & 0.014 & 60.5 \\
\hline S5 & 07-août-07 & 719986 & 1985413 & 1752 & 556 & 270 & 823 & 1590 & 0.015 & 47.1 \\
\hline S6 & 30-mai-07 & 720878 & 1985444 & 99 & 317 & 443 & 387 & 1721 & 0.317 & 15.1 \\
\hline \multicolumn{11}{|c|}{ Wastewater } \\
\hline EU & 30-mai-07 & 720328 & 1984707 & 1335 & 589 & 1165 & 527 & 1951 & 0.029 & 80.9 \\
\hline
\end{tabular}

690

691 Table 3. Results of $\mathrm{Cl}, \mathrm{Ca}, \mathrm{Na}, \mathrm{Mg}, \mathrm{HCO}_{3}$ and $\mathrm{Li}$ concentration $\left(\mu \mathrm{mol} \mathrm{L}{ }^{-1}\right.$ ) and $\delta^{7} \mathrm{Li}$ in

692 groundwater from the peatland (Q1 and -Q2), spring water S1 and S5 located on the

693 hillslope on the western side and S6 (emerging close to the outlet of the area), wastewater

694 EU and surface water R1 in the Narces de la Sauvetat peatland.

695

696

697

698

699

700 


\begin{tabular}{cccccc} 
River & $\mathbf{X}$ & $\mathbf{Y}$ & $\mathbf{L i}$ & $\delta^{7} \mathbf{L i}$ & $\mathbf{2 \sigma _ { m }}$ \\
\hline & & & $\mu$ mol. $^{-}$ & & \\
Couze Groire & 648269 & 2063602 & 2.35 & 5.8 & 0.1 \\
Couze Chaudefour & 643296 & 2062409 & 0.55 & 3.3 & 0.2 \\
Couze Pavin & 667041 & 2060952 & 1.75 & 6.3 & 0.1
\end{tabular}

701

702 Table 4. Results of $\mathrm{Li}$ concentration $\left(\mu \mathrm{mol} \mathrm{L}{ }^{-1}\right)$ and $\delta^{7} \mathrm{Li}$ in several surface-water samples 703 from the Massif Central.

704

705

706

707

708

709

710 